\title{
LETTING IT FLOW: TOWARDS A PHENOMENOLOGY OF WATER IN THE AGE OF MODERN TECHNOLOGY
}

\author{
Remmon E. Barbaza \\ Ateneo de Manila University, Philippines \\ rbarbaza@ateneo.edu
}

\begin{abstract}
This essay seeks to initiate a phenomenology of water in the age of modern technology within a Heideggerian framework. Insofar as it holds sway as the essence of modern technology, Ge-stell (enframing) blocks the appearance of water as water. Instead, like most other "natural resources," water appears as the resource that is extracted, manipulated, and made readily available for universal distribution and instant consumption, but detached from its origin in earth and sky. A disruption in the handiness of water, however, such as is occasioned by water shortage or massive flooding, offers the possibility of inviting human beings to recover their primordial relationship with water, as that on which their life depends and one that they cannot partake of in a sustainable way without a truthful and simple awareness of its origin.
\end{abstract}

Keywords

disconnectedness, distance, ecology, nearness, techné and poiésis

\section{About the author}

Remmon E. Barbaza is Associate Professor in Philosophy at the Ateneo de Manila University. He earned a PhD in Philosophy from the Hochschulefür Philosophie-München in Germany under the supervision of Prof. Dr. Gerd Haeffner, S.J. His dissertation Heidegger and a New Possibility of Dwelling was published in 2003 (Frankfurt: Peter Lang). His essay "There Where Nothing Happens: The Poetry of Space in Heidegger and Arellano" appears as a chapter in Heidegger and the Earth: Essays in Environmental Philosophy (U of Toronto P, 2009). His research interests include Heidegger, technology, language, environment, and translation. He is currently working on a translation of Heidegger texts into Filipino.

The shower made tautened drums of galvanized iron roofs and bounced off hastily summoned tarpaulins, seeking the quickest route back home to open water but foiled at every turn.

$$
\text { - Jose Dalisay, Soledad's Sister (3) }
$$

In his seminal lecture “The Question Concerning Technology," Heidegger juxtaposes two different experiences of the Rhine River: one that is uttered in a poem of Friedrich Hölderlin that bears the name of the river as its title, and another that is made possible by the presence of a hydroelectric plant built into the river (The Question 16). 
By juxtaposing these two experiences of the same river, Heidegger wishes to concretely illustrate how technology which, in its essence, is "a way of revealing," can determine the way a thing can appear, and therefore be experienced (The Question 12). Because the way of revealing that holds sway in modern technology is no longer poetic as it is in the primordial experience and understanding of technology, but now is rather characterized by a forceful and oftentimes aggressive "challenging forth" that subjects nature to an unreasonable demand for raw materials that are extracted, stockpiled, and made to stand for universal and instant availability - what Heidegger names as Ge-stell, or enframing - the river appears and is thus experienced differently in the age of modern technology (The Question 16-19).

In this essay I ask how in general water appears in the age of modern technology within the framework of Heideggerian phenomenology. In so doing we could take initial steps towards a phenomenology of water, something that has to be worked out more carefully and whose scope is certainly beyond the intent of the present paper. But two things need to be clarified at the outset, modern technology and Heideggerian phenomenology.

We already saw above how Heidegger sees modern technology as fundamentally distinct from primordial technology, but we need sufficient clarity about this claim insofar as it represents a key presupposition of this essay. In questioning the essence of technology, Heidegger directs our attention away from the merely instrumental and anthropological interpretation that limits the understanding of technology to its being an instrument and its belonging to human activity. He claims that if we went beyond this merely correct (versus true) interpretation of technology, we would inevitably see that technology belonged to "the realm of revealing," that is, to the realm of truth. And insofar as technology, primordially understood, belongs to the realm of revealing, it is also at the same time poetic (thus pointing to the primordial relation between techné and poiésis).

Now, while modern technology (insofar as it is still technology) is also a way of revealing, it is a fundamentally different way of revealing because the revealing that happens in it is no longer poetic but rather, as we saw above, more of "a challenging forth" not only of the natural resources but even more so of human beings themselves. Unless we see this fundamental and essential difference between modern technology and primordial technology, we are more likely to see the difference between the two merely in terms of advancement in development and sophistication, so that we say that the former is "high-tech" and the latter primitive. Thus we will also fail to see how, for example, in the age of modern technology, the earth now is revealed as "a coal mining district" or else "one huge gas station."

Now let us turn to Heidegger's phenomenology. In Being and Time, after a careful historicoetymological analysis of the word "phenomenology," Heidegger finally proposes a meaning: "Hence phenomenology means: apophainesthai ta phainomena-to let what shows itself be seen from itself, just as it shows itself from itself" (30). ${ }^{1}$ 
Let us dwell for a moment on this uniquely Heideggerian understanding of phenomenology. One thing that might readily strike the reader is that phenomenology, as Heidegger sees it, is not an intellectual activity, at least not primarily. There is not a single word in the definition that comes anywhere close to thinking. It is, rather, primarily an act of letting. One might ask: Through which human faculty is the act of letting accomplished? Perhaps, as we shall see later, the act of letting is not accomplished simply by a human faculty, but rather by the human being as a whole.

A second thing we realize from Heidegger's understanding of phenomenology is that what is let in the act of letting is the event of seeing - phenomenology is a letting-be-seen of something. Neither the act of letting nor the event of seeing is primarily associated with thinking, although "seeing" is indeed at times equated with understanding (but is nonetheless not entirely the same as thinking). I say here "the event of seeing" rather than "the act of seeing" in order to indicate that "letting something be seen" is not exactly the same as "seeing something." The latter implies human agency in seeing, whereas the former, by pointing to an event rather than an act, points to something that is beyond human agency.

Finally, we note from the same passage that the word "itself" appears five times. That this word appears five times (even six, if we include its root "it") in a single sentence is indeed quite striking. But the word appears there five or six times not simply because Heidegger employs a literary device for emphasis, but because his very understanding of phenomenology itself requires it so. It tells us not only that the experience of seeing is an event and therefore is not accomplished primarily through human agency, as we have seen above. It also tells us that it is the thing itself under consideration that tells us how it is to be seen. We do not show the thing. The thing itself shows itself, and shows itself in the manner that it does from itself. What phenomenology asks us to do is "simply" to let this self-showing happen, and thus to let the thing be seen.

Having now seen in broad strokes what Heidegger means by phenomenology, we are now in a position to work out a phenomenology of water. A phenomenology of water, thus, would mean letting water be seen from itself, just as water shows itself from itself. Water is a phenomenon insofar as it shows itself. But it must be allowed to show itself, "just as it shows itself from itself." What we are concerned here is therefore not just the showing itself of water, but the showing itself of water "just as it shows itself from itself."

How does water show itself and from itself? We must first recall from Being and Time that for the most part of our lives anything at all appears within the context of everyday human existencewith all the things we preoccupy ourselves with and the useful things we take hold of and employ to meet our needs, to accomplish tasks, and to achieve objective goals. We are always already in a world (which means a horizon of meaning, a context or web of references), and we always already 
know our way about our daily lives. Water, like the other things we use in our daily lives, appears to us as handy, made readily available by the faucet in our kitchen or the shower in our bathroom. We do not really pay attention to water, which is only in keeping with the being of useful things as they recede into the background and remain inconspicuous for the most part. As Heidegger observes, "what is peculiar to what is initially at hand is that it withdraws, so to speak, in its character of handiness in order to be really handy" (Being and Time 65).

But useful things can sometimes rise out of their inconspicuousness and make themselves present before us, as happens when they malfunction, break down, run out, or get lost. "When we discover its unusability," Heidegger says, "the thing becomes conspicuous" (Being and Time 68). What is "initially and for the most part" ready-to-hand (zuhanden), for the moment becomes present-at-hand (vorhanden). ${ }^{2} \mathrm{~A}$ breakdown of a tool or a piece of equipment can cause an interruption to the everyday and familiar character of our human existence. We strive to bring our lives back to normalcy by bringing back our things to their normal, useful state. And then we are back to our familiar, everyday world. "Pure objective presence," notes Heidegger, "makes itself known in the useful thing only to withdraw again into the handiness of what is taken care of, that is, of what is being put back into repair" (Being and Time 68).

Interruptions to the normal flow of our daily existence are not always only negative. They can also become opportunities for us to take a second look at our lives and how we stand in relation to the things that have broken down or been removed from us. We recall how in Chinese language the word for crisis denotes both danger and opportunity.

In recent years, three events interrupted the daily lives of Filipinos in relation to water. The first was the massive flooding in September 2009, which submerged about 80 percent of Metro Manila after a month-long worth of rain poured down in just nine hours at the height of typhoon Ketsana (locally known as Ondoy), killing hundreds of people and destroying their property. The second was the water crisis that hit the megacity in July 2010, affecting more than a million residents as the water supply was cut in several areas because the water level in Angat Dam had gone way below the critical point and there was no sight of rains coming to restore it to normal level. Most recently, in December 2011, tropical storm Washi (locally known as Sendong) unleashed floods that caused massive destruction in northern Mindanao.

When, in our concrete experience of overabundance and scarcity of water in the Philippines, particularly in the megacity that is Metro Manila, water appears as something that on the one hand overwhelms us and on the other eludes us, we can say that water now can begin to appear to us on its own terms. Water now can appear to us in a way that makes us realize that we do not really have mastery over it despite all our technologies of its capture, storage, and distribution. 
Because of water calamities and water shortage, water is now coming out of its inconspicuousness and begins to make us question the way we stand in relation to it. One of the more concrete outcomes of the recent water crisis in Metro Manila, for example, is the realization of our ignorance even about the more basic facts about water. It would not be surprising to find out, for example, that most of the residents in Metro Manila did not realize that the water that came out of their faucets had to travel a long way before reaching their kitchens and bathrooms. Angat Dam, which meets 97\% of Metro Manila's water demand and Central Luzon's irrigation needs, is about 60 kilometers northeast of the megacity (Reyes-Estrope).

What does it mean, concretely for our human existence, if we are virtually oblivious to the source of our water? What does it mean, concretely for our human existence, if water appears to us as something readily available and can be accessed in an instant by the mere turning of a faucet or the purchase of bottled mineral water?

Now that the water crisis has made it possible for me to become aware, at the very least, that the water that comes to me through the faucet has traveled some 60 kilometers, I become aware that this thing without which I could not live is something that is sourced from quite a distance from where I live, from where I lead my human existence. I become aware that modern technology has made it possible for us to render water readily available in our very own homes, even if its source is 60 kilometers away.

But in bridging this distance of 60 kilometers, has not modern technology also removed my connection to my immediate surrounding, namely the very piece of land on which I live and from which otherwise I would perhaps be drawing water by way of a hand pump, a well, or a spring? Perhaps something else is happening in a water system where water is made to travel through several kilometers, from dams and water reservoirs, through filtration plants and underground pipes, and finally to the faucet in my home. The negation of the distance of 60 kilometers does not bring me to the nearness of water. That water comes out readily through the faucet in my own home does not make me experience the distance that it has traveled from its source in Angat Dam, nor does it make me experience its nearness right in my own home. In the age of modern technology that made possible the construction of large dams and water and sewage systems, water is neither near nor far. ${ }^{3}$

In a lecture that he wrote at around the same period as the one on technology, "The Thing," Heidegger precisely speaks of how, in the modern technological age, the abolition of distance does not bring about nearness (Poetry 106). Modern technology's ability to bridge distances - whether by way of transportation or communication - does not bring about nearness. Heidegger's questions are as prophetic and urgent as when they were first uttered more than half a century ago: “What is 
happening here when, as a result of the abolition of great distances, everything is equally far and equally near? What is this uniformity in which everything is neither far nor near-is, as it were, without distance?" (Poetry 166)

Modern technology, as a particular way of revealing, brings about disconnectedness. Human beings are disconnected from their immediate environment, and their perceived technical mastery over nature only proves to be an illusion. For instance, I know that at any time we run out of water, at any time water ceases to flow through our faucets (for one, the Angat dam is said to be sitting on a fault line), I could no longer lead my life the usual way. And since there is no well or spring, not even a hand pump, anywhere within my neighborhood, a complete shutdown of the water supply would force me to move to another place where there is water. Mawalan ka na ng kuryente, huwag lang tubig, as we say in Filipino. Better to be without electricity than without water.

Disconnectedness, the loss of nearness, and the illusion of technical mastery over nature are also revealed in our loss of basic survival instincts, as McWhorter and Stenstad reflect in their dialogue, “Eating Ereignis, or: Conversation on a Suburban Lawn.” McWhorter recalls:

One day in the late spring of 2005, I found myself standing at the edge of a university quadrangle on a beautiful afternoon. The scene before me was predictable, at least for anybody who has ever been on a university quad on a beautiful afternoon. Sunbathing undergraduates laughed and talked, munching snacks from nearby vending machines; squirrels darted to and fro foraging for acorns; busy birds pecked at fat red worms. I had witnessed the same scene hundreds of times, but for some reason that day it raised a thought in me that hit me like a lightning bolt: we don't know the first thing about dwelling ... In contrast to the birds and the squirrels, we modern-day humans don't know the first thing about dwelling. Not even the first thing. I found that thought staggering and humbling. And frightening. Not only is the food that most of us eat not a product of the land we occupy - the undergraduates' snack food was trucked in from hundreds, maybe thousands of miles away - but we have no idea which products of the land we occupy are edible. If the trucks stopped coming, most of us would starve. (215)

Within the enframed age of modern technology, water, like most other things, appears as a "resource," a term which is not altogether neutral given the compulsion to forcibly extract "natural resources" from the earth. The ensuing objectification and commodification of water already presupposes the severance of our primordial relationship with something that not only sustains 
our life but also accompanies us through the many aspects of our existence, as when we use water in religious rituals such as baptism or house blessing, or when we scatter the ashen remains of our loved ones into the open sea.

This severance of relationship, and thereby the disappearance of the nearness of water to our lives, can also be seen in the way water can appear as something alien. In his analysis of cultural theory and types of water, Gyawali illustrates how water can appear as "a 'mirage' in ads," especially among the poor who have resigned themselves to fate, as resources such as water are not justly distributed but handed out as if in a lottery; or how, especially among those who tend towards individualism and presuppose an abundance rather than scarcity of water, water appears in the form of "priced, glamorized 'bottled water"' (20).

But a crisis can serve to jolt us out of our illusions, as when water suddenly runs out or when floodwaters come rushing in the middle of the night. The water crisis can become an occasion for us to imagine what it could be if we ran out of water and, thus, in becoming aware of it, let water appear on its own terms. "Ecological thinking," says Fesmire, "is fundamentally imaginative," as he calls for the cultivation of "ecological imagination" (183). The act of imagining can be said to be part of letting-be, for letting something be seen can also mean imagining how that thing can manifest itself before us on its own terms. When, for instance, one finds oneself in a situation of injustice, and prays that there be justice ("Let there be justice"), one is imagining a possibility, but a possibility that really belongs to the essence of the very thing hoped for.

And so when, in the midst of the objectification and commodification of water, we come to a realization of the need to first of all let water be, to let water show itself on its own terms, then we are doing in practical terms a phenomenology of water. This can be accomplished not just by way of an actual philosophical, phenomenological reflection or analysis, but most of all by way of poetry, through which alone nearness can come to be.

We recall how Heidegger, by way of a poem by Friedrich Hölderlin, in the end points to poetry (or art, since "the poetical thoroughly pervades every art") as holding within it the "saving power" that can help human beings rediscover their bearings even as they find themselves still under the sway of modern technology (The Question 34-35). "Salvation" cannot be willed in any case. Neither can or should human beings will to live without technology - for that is neither possible nor desirable and, even more, a fundamental misunderstanding of the essence of technology (Discourse 43-54). Insofar as the close relation between techné and poiésis that primordial technology preserves is undone in the age of modern technology, we can indeed see that "salvation" lies in poetry.

In what way does salvation lie in poetry? Where modern technology abolishes all distances, as we saw earlier, poetry preserves the nearness of things. And since to dwell is to stay in the 
nearness of things, then it is through the poetic alone that we can dwell on earth - with its water and air, trees and animals, with the changes of its seasons. If we then try to imagine water as showing itself on its own terms, if we let water be seen as it shows itself, then it will have to mean the recovery of the nearness of water.

But what is nearness? This is of course one of the central questions of the lecture, "The Thing," and we do not wish to go at length into how Heidegger approached it. It would suffice here to say that nearness - primordial nearness, that is - is not to be understood here as the objective distance between two points. As one can derive from the thoughts of Heidegger, in science strictly speaking there is no such thing as near or far. Rather, the primordial nearness in which we all dwell makes possible the "near" and the "far," just as primordial space makes possible different senses and levels of "spaces," "locations," "rooms," etc., because "Da-sein is spatial in a primordial sense" (Being and Time 103; Poetry 154-57).

We know that the history of civilization is always closely tied with water. Nearly every great city was established near rivers or by the sea. And in any case human life is not possible in places where there is no freshwater or no possibility of accessing it from a neighboring place. This historical fact alone-that we build our lives around water-manifests our dependence as human beings and communities on water, particularly freshwater. But it seemed that we have reversed this relation of dependence, making water adjust to our lives and projects and ambitions, as when residential communities built on watersheds or huge dams erected on rivers force water to redirect itself as it seeks its own level, and many times with deadly repercussions.

Perhaps there is indeed some truth in the saying that nature does not know catastrophes, and that water always seeks its own level. But perhaps there is also truth in the intuition that nature itself has its own wisdom that we human beings must allow to make itself manifest, and from which human beings must learn, so that in letting water find its own level according to the designs of nature, we can also begin to level ourselves with water, with nature as a whole, in a way that reflects the delicate balance of our relationship with all beings as a whole.

The water crisis that is affecting more and more parts of the world is bringing together scientific experts, government officials, NGO workers, academics, and ordinary citizens in their desire to address our common issues concerning water. The levels of responses range from the practical and technical, to the ethical and theoretical. But overall the response is generally framed as a question of better water management and governance. We want to manage and govern water well.

This predominantly managerial and technical approach to water, however, should give us pause. McWhorter offers an incisive critique of the managerial approach that dominates Western culture, asking whether our primarily managerial approach to environment through the use of 
modern science and technology could very well be just a management of our guilt (which is just the other side of claiming success or superiority over nature) ("Guilt as Management Technology").

Brown and Schmidt, for their part, claim that one of the first things we need to do is "to critically evaluate ideas in the broader Western narrative that have tended to privilege human welfare, scientific knowledge, and technological know-how," and thereby "to recognize that all knowledge is partial and limited" and, finally, suggest that we take the stance of what they call "compassionate retreat" (265-66). Retreating, or taking a step back, as opposed to the aggressive stance of control and management, is precisely what is called for by the disposition of letting, of letting-be and letting-be-seen.

To a large extent of course the goals of better water management and governance are necessary and the efforts made towards it laudable. But we might do well to make room for the question whether an approach that is primarily managerial and technical is enough to make us realize the kind of stance we need to adopt in relation to water, or to know whether we need to restore a primordial relationship with water that we lost in the midst of modern technology. As Heidegger says, "unless man first establishes himself beforehand in the space proper to his essence and there takes up his dwelling, he will not be capable of anything essential within the destining now holding sway" (The Question 39). For a primarily managerial or technical approach to our water issues does not really bring us to that "space proper to our essence," where we might be able "to take up our dwelling," nor does it make it possible for us to take the stance of letting that phenomenology really is.

Such a stance of letting is perhaps the hardest to take, but it is the only one that can make it possible for water to show itself as we restrain ourselves from foiling it at every turn as it, like us, seeks its way back home. 


\section{NOTES}

1. The original runs: "Phänomenologie sagt dann: Das was sich zeigt, so wie es sich von ihm selbst her zeigt, von ihm selbst her sehen lassen" (Heidegger, Sein und Zeit 34).

2. "Zunächst und zumeist." This is a technical expression that Heidegger employs througout Being and Time. It indicates the pre-philosophical, pre-scientific, pre-ontological experience that makes up human existence for the most part. I believe it is Heidegger's other way of saying "everyday."

3. One can of course object here by saying that aqueducts existed in antiquity, and how, for example, the famous Roman aqueducts covered a combined distance of about 500 kilometers. But we are not to understand the "age of modern technology" historiographically, in the same way as we understand the "age of iron," or the "age of reason," which can somehow be dated. Moreover, when Heidegger claims that enframing holds sway in the age of modern technology, it should not be taken to mean as precluding pockets of freedom and poetic experience. More important, we must not understand "space" and "distance" in terms of measurable dimensions, for "nearness" in Heidegger has to be understood in its primordial sense. The admistrators, managers, and engineers of a large dam, for example, can be the ones physically closest to the source of water, and yet by their very stance of objectification and commodication are farthest removed from water. One can also be engaged in the humanities and teach poetry or literature, or work in an art museum, and still be predominantly calculating and objectifying in one's relationship with things in general. 


\section{WORKS CITED}

Brown, Peter G., and Jeremy J. Schmidt. "An Ethic of Compassionate Retreat." Water Ethics: Foundational Readings for Students and Professionals. Eds. Peter G. Brown and Jeremy J. Schmidt. Washington, DC: Island Press, 2010. 265-86. Print.

Dalisay, Jose. Soledad's Sister. Manila: Anvil, 2008. Print.

Fesmire, Steven. “Ecological Imagination." Environmental Ethics 32.2 (2010): 183-203. Print.

Gyawali, Dipak. "Water and Conflict: Whose Ethics is to Prevail?" Water Ethics: Marcelino Botin Water Forum 2007. Eds. M. Ramón Llamas, Luis Martinez-Cortina, and Aditi Mukherji. Leiden: CRC Press/ Balkema, 2009. 13-24. Print.

Heidegger, Martin. Being and Time: A Translation of Sein und Zeit. Trans. Joan Stambaugh. New York: State U of New York P, 1996. Print.

---. Discourse on Thinking. Trans. Johh M. Anderson and E. Hans Freund. New York: Harper Torchbooks, 1969. 43-57. Print.

---. Poetry, Language, Thought. Trans. Albert Hofstadter. New York: Harper Perennial, 1975. Print.

---. The Question Concerning Technology and Other Essays. Trans. William Lovitt. New York: Harper Torchbooks, 1977. Print.

---. Sein und Zeit. 17. Aufl. Tübingen: Max Niemeyer, 1993. Print.

McWhorter, Ladelle. “Guilt as Management Technology: A Call to Heideggerian Reflection.” Heidegger and the Earth: Essays in Environmental Philosophy. 2nd, rev. ed. Eds. Ladelle McWhorter and Gail Stenstad. Toronto: U of Toronto P, 2009, 5-16. Print.

McWhorter, Ladelle, and Gail Stenstad. "Eating Ereignis, or: Conversation on a Suburban Lawn." Heidegger and the Earth: Essays in Environmental Philosophy. 2nd, rev. ed. Eds. Ladelle McWhorter and Gail Stenstad. Toronto: U of Toronto P, 2009, 215-35. Print.

Reyes-Estrope, Carmela. "Angat Dam to Shut Down for 3 Days to 'Rest."' Inquirer.net. Web. 2 July 2010. 